\title{
Pengaruh Kepemimpinan, Kepuasan Kerja Dan Motivasi Kerja Terhadap Loyalitas Karyawan
}

\author{
Lola Melino Citra \\ Muhammad Fahmi
}

Program Studi Magister Manajemen, Universitas Muhammadiyah Sumatera Utara Medan, Indonesia Jl. Denai No. 217, Tegal Sari Mandala II, Medan Denai, Kota Medan, Sumatera Utara 20371

Email: muhammadfahmi@umsu.ac.id

\begin{abstract}
Abstrak.Tujuan perusahaan untuk memperoleh laba maksimum hanya dapat dicapai dengan mengelola semua sumber daya yang dimiliki perusahaan, khususnya sumber daya manusia atau tenaga kerja. Tenaga kerja mempunyai peranan yang dominan karena merupakan faktor penggerak bagi semua sumber daya lainnya dalam perusahaan. Oleh karena itu keberhasilan perusahaan sering juga diidentikkan dengan tingkat keberhasilan tenaga kerja secara keseluruhan.Penelitian ini bertujuan untuk menguji pengaruh dari kepemimpinan, kepuasan kerja dan motivasi terhadap loyalitas karyawan, Pendekatan penelitian yang digunakan adalah asosiatif, dengan lokasi di PT Perkebunan Nusantara IV (Persero) dari Desember 2018-Maret 2019, populasi penelitian berjumlah 575 orang, adapun teknik pengambilan sampel yang digunakan adalah teknik slovin, dengan jumlah sampel sebanyak 85 orang, dengan melakukan pengumpulan data dengan metode penyebaran angket, dan menggunakan teknik analisis regresi linier berganda menggunakan alat aplikasi SPSS IBM 21. Hasil penelitian menunjukkan Kepemimpinan memiliki pengaruh terhadap loyalitas karyawan PT Perkebunan Nusantara (Persero) IV, Kepuasan Kerja tidak memiliki pengaruh terhadap loyalitas karyawan PT Perkebunan Nusantara (Persero) IV, Motivasi memiliki pengaruh terhadap loyalitas karyawan PT Perkebunan Nusantara (Persero) IV dan Kepemimpinan, Kepuasan Kerja dan Motivasi secara bersama-sama memiliki pengaruh terhadap loyalitas karyawan PT Perkebunan Nusantara (Persero) IV.
\end{abstract}

Kata kunci: Kepemimpinan, Kepuasan Kerja, Motivasi, Loyalitas Karyawan

\begin{abstract}
The purpose of the company to obtain maximum profit can only be achieved by managing all the resources owned by the company, especially human resources or labor. Labor has a dominant role because it is a driving factor for all other resources in the company. Therefore the success of the company is often also identified with the success rate of the workforce as a whole. The aim of this study to examine the effect of leadership, job satisfaction and motivation on employee loyalty, The research approach used is associative, with a location at PT Perkebunan Nusantara IV (Persero) from December 2018-March 2019, the study population amounted to 575 people, while the sampling technique used was Slovin technique, with a sample of 85 people, by collecting data using the questionnaire method, and using multiple linear regression analysis techniques using the IBM SPSS 21 application tool. The results showed that Leadership had an influence on employee loyalty of PT Perkebunan Nusantara (Persero) IV, Job Satisfaction had no influence on employee loyalty of PT Perkebunan Nusantara (Persero) IV, Motivation had an influence on employee loyalty of PT Perkebunan Nusantara (Persero) IV and Leadership, Satisfaction Work and Motivation together have an influence on employee loyalty of PT Perkebunan Nusantara (Persero) IV.
\end{abstract}

Keywords : Leadership, Job Satisfaction, Employee Motivation, Loyalty

\section{PENDAHULUAN}

Setiap individu berkeinginan untuk melakukan pekerjaan dengan baik dan memberikan sumbangan penting kepada organisasi atau perusahaannya, membawa banyak individu untuk mendorong diri sendiri melebihi batas kemampuan yang normal sampai mencapai keadaan yang dinamakan keletihan kerja yang berdampak pada ketegangan di tempat kerja, dimana hal 
tersebut bisa dikatakan merupakan ancaman yang serius, dimana hal itu dapat terjadi pada setiap jajaran yang ada di dalam perusahaan, baik atasan maupun bawahan, baik staff maupun pimpinan perusahaan.

Loyalitas karyawan merupakan sikap positif karyawan terhadap perusahaan tempat dia bekerja. Pegawai dengan sikap loyalitas yang tinggi dapat bekerja tidak hanya untuk dirinya sendiri tetapi juga untuk kepentingan perusahaan. Menurut Hasibuan, (2014) bahwa loyalitas atau kesetiaan merupakan salah satu unsur yang digunakan dalam penilaian karyawan yang mencakup kesetiaan terhadap pekerjaannya, jabatannya dan organisasi. Kesetiaan ini dicerminkan oleh kesediaan karyawan menjaga dan membela organisasi di dalam maupun di luar pekerjaan dari rongrongan orang yang tidak bertanggungjawab. Loyalitas dapat dikatakan sebagai kesetiaan seseorang terhadap suatu hal yang bukan hanya berupa kesetiaan fisik semata, namun lebih pada kesetiaan non fisik seperti pikiran dan perhatian. Loyalitas para karyawan dalam suatu organisasi itu mutlak diperlukan demi kesuksesan organisasi itu sendiri.

Maka disinilah peran dan tugas sebenarnya seorang pimpinan, segala sikap, keputusan dan tindakan seorang pemimpin tentunya sangat berpengaruh bahkan berperan dalam hal ini, sehingga mampu menjadi tolak ukur tindakan dan motivasi bagi para pegawai dalam segala bentuk serta aktivitas pekerjaan yang positif, yang nantinya mampu membangun semangat dan kepuasan kerja bahkan loyalitas kerja karyawan itu sendiri. Oleh karena itu peranan, pengaruh dari gaya seseorang dalam memimpin pun sangat menjadi faktor penentu bagi peningkatan dan penurunan loyalitas karyawan itu sendiri. Maka, sehubungan dengan hal tersebut jelas dalam sebuah organisasi dibutuhkan komunikasi yang efektif. Menurut (Hasibuan, 2014), kepemimpinan adalah kemampuan seseorang untuk mempengaruhi orang lain. Dalam hal ini para bawahannya sedemikian rupa sehingga orang lain itu mau melakukan kehendak pimpinan meskipun secara pribadi hal itu mungkin tidak disenanginya. Kepemimpian sebagai upaya mempengaruhi bawahan melalui proses komunikasi langsung atau tidak langsung demi mencapai sasaran tertentu, menunjukkan bahwa melibatkan penggunaan pengaruh oleh sebab itu semua hubungan personal dapat merupakan upaya kepemimpinan.

Elemen kedua dari definisi di atas yakni terkait pentingnya proses komunikasi, baik komunikasi langsung atau tidak langsung, ketepatan dan kejelasan komunikasi akan mempengaruhi prilaku dan loyaltias kerja karyawan itu sendiri. Elemen yang terakhir yaitu pencapaian sasaran, dimana pemimpin yang efektif mau tidak mau mungkin harus berurusan dengan sasaran individu, kelompok juga organisasi. Maka dari itu keefektifan seorang pemimpin khususnya dilihat dari ukuran tingkat pencapaian satu atau kombinasi tujuan..

PT. Perkebunan Nusantara IV (Persero) Medan masih memiliki kekurangan interaksi antara pimpinan dengan para karyawannya. Perusahaan ini masih cenderung menganut memberikan perintah secara langsung kepada karyawannya tanpa menciptakan suatu interaksi yang efektif sehingga hal ini menyebabkan para karyawannya melakukan pekerjaan tersebut hanya sebatas kewajiban dan bukan sebagai tanggung jawab yang didasari oleh rasa memiliki perusahaan tersebut. Pimpinan seharusnya mampu berinteraksi secara maksimal dalam mengorganisasikan para karyawan dalam melakukan tugas-tugas pada hari-hari selanjutnya.

Selain kepemimpinan, salah satu faktor yang menyebabkan naik atau turunnya loyalitas kerja karyawan adalah kepuasan kerja. Menurut Colquitt, LePine, \& Wesson, (2012), Kepuasan kerja adalah tingkat perasaan menyenangkan yang diperoleh dari penilaian pekerjaan seseorang atau pengalaman kerja. Untuk itu merupakan keharusan bagi perusahaan untuk mengenali faktor-faktor apa saja yang membuat pegawai puas bekerja di perusahaan. Dengan tercapainya kepuasan kerja pegawai, loyalitas pun akan meningkat. Banyak faktor yang mempengaruhi kepuasan kerja pegawai, diantaranya adalah kesesuaian pekerjaan, kebijaksanaan organisasi 
termasuk kesempatan untuk berkembang, lingkungan kerja dan perilaku atasan. Jika pegawai merasa tidak puas maka ada beberapa hal yang mungkin akan dilakukan yaitu, pegawai akan berfikir untuk meninggalkan pekerjaan. Kepuasan kerja mengekspresikan sejumlah kesesuaian antara harapan seseorang tentang pekerjaannya yang dapat berupa prestasi kerja yang diberikan oleh perusahaan dan imbalan yang diberikan atas pekerjaannya. Pada hakekatnya seseorang didorong untuk beraktivitas karena dia berharap bahwa hal tersebut akan membawa keadaan yang lebih baik memuaskan dari pada keadaan sekarang. Jadi bekerja adalah suatu bentuk aktivitas yang bertujuan untuk mendapatkan kepuasan kerja.

Pegawai yang memiliki loyalitas kerja yang tinggi akan meningkatkan kehidupan organisasi atau perusahaan. Loyalitas kerja dapat dilihat dari mereka merasa senang dengan pekerjaannya. Mereka akan memberikan lebih banyak perhatian, imajinasi dan keterampilan dalam pekerjaannya. Dengan demikian diperlukan suatu motivator bagi pegawai yaitu berupa pemenuhan kebutuhan fisik dan non fisik. Dengan terpenuhinya kebutuhan tersebut maka pegawai akan bersedia bekerja dan melaksanakan tugasnya dengan baik. Mereka akan lebih memusatkan perhatiannya terhadap tugas dan tanggung jawabnya, sehingga hasil pekerjaan yang dicapai dapat meningkat. Untuk itulah dibutuhkan suatu dorongan bagi pegawai di dalam menyelenggarakan kegiatan di suatu perusahaan. Dorongan itulah yang disebut motivasi (Arianty, Bahagia, Lubis, \& Siswadi, 2016).

Robert Heller (Wibowo, 2013) menyatakan bahwa motivasi adalah keinginan untuk bertindak. Dengan adanya motivasi dapat merangsang pegawai untuk lebih menggerakan tenaga dan pikiran dalam merealisasikan tujuan perusahaan. Apabila kebutuhan akan hal ini terpenuhi maka akan timbul kepuasan dan kelancaran terhadap peningkatan loyalitas karyawan. Loyalitas kerja akan terwujud jika para pegawai mempunyai kemampuan dalam menyelesaikan pekerjaan atau tugas yang menjadi tanggungjawabnya masing-masing. Oleh karena itu pimpinan harus dapat memberikan suatu dorongan atau motivasi pada para pegawai. Masalah yang sering dihadapi pimpinan organisasi adalah bagaimana mencari cara yang paling terbaik yang harus ditempuh agar dapat menggerakan dan meningkatkan loyalitas karyawannya agar secara sadar dan bertanggungjawab melaksanakan tugas dengan sebaik-baiknya, karena setiap karyawan mempunyai kebutuhan dan keinginan yang berbeda-beda sehingga pimpinan harus mengerti dan memahami kebutuhan serta keinginan para anggotanya.

\section{LANDASAN TEORI}

\section{Loyalitas Kerja}

Loyalitas mencerminkan kesetiaan dari karyawan kepada perusahaan dimana tempatnya bekerja. Menurut (Siagian, 2014) bahwa loyalitas adalah suatu kecenderungan karyawan untuk tidak pindah ke perusahaan lain sebab loyalitas dapat mempengaruhi pada kenyamanan karyawan untuk bekerja pada suatu perusahaan. Menurut (Nitisemito, 2011) bahwa loyalitas merupakan suatu sikap mental karyawan yang ditunjukkan kepada keberadaan perusahaan sehingga karyawan akan tetap bertahan dalam perusahaan, meskipun perusahaan tersebut maju atau mundur. Berdasarkan loyalitas yang dimiliki oleh karyawan, ada banyak factor-faktor yang mempengaruhi loyalitas dari karyawan. Menurut (Almasdi, 2012) faktor-faktor yang mempengaruhi loyalitas karyawan sebagai berikut 1) faktor Rasional. Menyangkut hal-hal yang bisa dijelaskan secara logis, seperti: gaji, bonus, jenjang karir dan fasilitas-fasilitas yang diberikan lembaga kepada karyawan. 2) faktor Emosional: Menyangkut perasaan atau ekspresi diri seperti: pekerjaan yang menantang, lingkungan kerja yang mendukung, perasaan aman karena perusahaan merupakan tempat bekerja dalam jangka panjang, pemimpin yang berkharisma, pekerjaan yang membanggakan, penghargaan-penghargaan yang diberikan perusahaan dan budaya kerja. 3) faktor Kepribadian. Menyangkut sifat, 
karakter, tempramen yang dimiliki oleh karyawan. Danim dalam penelitian (Putri, 2014) loyalitas merupakan sikap mental karyawan yang ditunjukan pada keberadaan perusahaan. Adapun indikator loyalitas kerja karyawan adalah : menaati peraturan, mampu bekerja dengan baik, tepat waktu, berani mengambil resiko, memiliki ide kreatif tanpa paksaan, melaksanakan tugas tanpa paksaan, tidak menyalahgunakan wewenang, melaporkan hasil kerja pada atasan.

\section{Kepemimpinan}

Menurut Sharma \& Jain dalam (Mujiatun, Jufrizen, \& Ritonga, 2019), kepemimpinan merupakan proses dimana seseorang mempengaruhi orang lain untuk mencapai tujuan dan mengarahkannya dengan cara yang lebih kohesif dan koheren. Kepemimpinan merupakan faktor yang menentukan dalam suatu perusahaan. Menurut (Sutikno, 2014), kepemimpinan dalam organisasi diarahkan untuk mempengaruhi orang-orang yang dipimpinnya, agar mau berbuat seperti yang diharapkan ataupun diarahkan oleh orang lain yang memimpinnya. Menurut (Yukl, 2010) menyatakan bahwa Kepemimpinan adalah proses mempengaruhi orang lain untuk memahami dan menyetujui apa yang dibutuhkan dalam melaksanakan tugas dan bagaimana melaksanakan tugas itu, serta proses unutk memfasilitasi upaya individu dan kolektif guna mencapai tujuan bersama. Sedangkan (Kartono, 2014) mengatakan Kepemimpinan adalah suatu bakat yang diperoleh orang sebagai kemampuan istimewa yang di bawa sejak lahir. Menurut Bangun (2012) kepemimpinan adalah suatu proses untuk mengarahkan dan mempengaruhi orang lain agar mau melaksanakan tugasnya untuk mencapai tujuan organisasi. Menurut (Setiawan \& Muhith, 2013) ada beberapa faktor yang mempunyai relevansi atau pengaruh positif terhadap proses kepemimpinan dalam organisasi, yaitu: (1) kepribadian (personality), (2) harapan dan perilaku atasan, (3) karakteristik, harapan, dan perilaku bawahan, (4) kebutuhan tugas, (5) iklim dan kebijakan organisasi.menurut siagian (2012), indikator-indikator kepemimpinan sebagai berikut: (a) iklim saling mempercayai, (b) penghargaan terhadap ide bawahan, (c) memperhitungkan perasaan para bawahan, (d) perhatian pada kenyamanan kerja bagi para bawahan, (e) perhatian pada kesejahteraan bawahan, (f) pengakuan atas status para bawahan secara tepat dan proposional, (g) memperhitungkan faktor kepuasan kerja para bawahan dalam menyelesaikan tugas-tugas yang dipercayakan padanya. Siagian, (2014) mengatakan indikator kepemimpinan adalah sebagai berikut: 1) kemampuan mengambil keputusan, 2) kemampuan memotivasi, 3) kemampuan komunikasi, 4) kemampuan mengendalikan bawahan, 5) tanggung jawab, dan 6) kemampuan mengendalikan emosional

\section{Kepuasan Kerja}

Kepuasan kerja pada dasarnya merupakan sesuatu yang bersifat individual, kerean setiap individu memiliki tingkat kepuasan yang berbeda-beda sesuai dengan sistem nilai yang berlaku pada dirinya. Kepuasan kerja merupakan evaluasi yang menggambarkan seseorang atas perasaan sikap senang atau tidak senang, puas atau tidak puas dalam bekerja. Kepuasaan kerja pegawai adalah suatu fenomena yang perlu dicermati oleh pimpinan organisasi (Jufrizen, 2016). Menurut (Robbins \& Judge, 2011) mendefinisikan "Kepuasan kerja sebagai sikap umum terhadap pekerjaan seseorang yang menunjukkan perbedaan antara jumlah penghargaan yang diterima pekerja dan jumlah yang diyakini oleh pekerja yang seharusnya diterima". Sedangkan McShane dan Von Glinow (Wibowo, 2006), memandang kepuasan kerja sebagai evaluasi seseorang atas pekerjaannya dan konteks pekerjaan. Keith Davis (Mangkunegara, 2017) mengemukakan bahwa "Kepuasan kerja dalah perasaan menyokong atau tidak menyokong yang dialami pegawai dalam bekerja”. Menurut Robbins (2008) menyatakan 
bahwa Kepuasan kerja adalah sikap umum terhadap pekerjaan seseorang. Yang menunjukan perbedaan antara jumlah penghargaan yang diterima pekerja dan jumlah yang mereka yakini seharusnya mereka terima, menurut (Mangkunegara, 2017) menyatakan bahwa Kepuasan kerja adalah suatu perasaan yang menyokong diri karyawan yang berhubungan dengan pekerjaannya maupun dengan kondisi dirinya, menurut (Hasibuan, 2014) menyatakan bahwa Kepuasan kerja adalah sikap emosinal yang menyenangkan dan mencintai pekerjaannya. Sikap ini dicerminkan oleh moral kerja, kedesiplinan, dan prestasi kerja. kepuasan kerja dinikmati dalam pekerjaan, luar pekerjaan, dan kombinasi antara keduanya.

Banyak faktor yang mempengaruhi kepuasan jerja karyawan. Faktor-faktor itu sendiri dalam peranannya memberikan kepuasan kepada karyawan bergantung pada pribadi masing-masing karyawan. Faktor-faktor yang mempengaruhi kepuasan menurut (Hasibuan, 2014) adalah sebagai berikut: 1) kerja yang menantang secara mental 2) penghargaan yang sesuai 3) kondisi kerja yang mendukung 4) rekan sekerja yang mendukung. Sedangkan menurut (Mangkunegara, 2017) adalah sebagai berikut: 1) faktor karyawan, yaitu kecerdasan IQ, kecakapan khusus, umur, jenis kelamin, kondisi fisik, pendidikan, pengalaman kerja, masa kerja, kepribadian, emosi, cara berpikir, persepsi, dan sikap kerja 2) faktor pekerjaan, yaitu jenis pekerjaan, struktur organisasi, pangkat (golongan), kedudukan, mutu pengawas, jaminan finansial, kesempatan promosi jabatan, interaksi sosial, dan hubungan kerja. Menurut (Robbins \& Judge, 2011) indikator kepuasan kerja yaitu sebagai berikut : 1) pekerjaan 2) upah 3) promosi 4) pengawas 5) rekan kerja. Menurut (Luthans, 2010) indikator kepuasan kerja yaitu sebagai berikut : 1) pekerjaan itu sendiri 2) gaji 3) promosi 4) supervisi 5) rekan kerja 6) kondisi kerja.

\section{Motivasi}

Motivasi merupakan salah satu hal yang mempengaruhi prilaku manusia. Motivasi disebut juga sebagai pendorong, keinginan, pendukung atau kebutuhankebutuhan yang dapat membuat seseorang bersemangat dan termotivasi untuk mengurangi serta memenuhi dorongan diri sendiri, sehingga dapat bertindak dan berbuat menurut cara-cara tertentu yang akan membawa ke arah yang optimal (Jufrizen, 2017). Menurut (Hasibuan, 2014), motivasi mempersoalkan bagaimana cara mendorong gairah kerja bawahan, agar mereka mau bekerja keras dengan memberikan semua kemampuan dan keterampilan untuk mewujudkan tujuan perusahaan. Menurut (Soeroso, 2004) motivasi merupakan suatu proses psikologis yang memperlihatkan interaksi antara sikap, kebutuhan, persepsi, dan keputusan yang terjadi pada seseorang. Dan motivasi sebagai proses psikologis timbul dari faktor dalam diri orang-orang itu sendiri yang disebut faktorintrinsik atau faktor dari luar diri yang disebut factor ekstrinsik. Menurut (Gomes, 2009) mengemukakan sebagai berikut motivasi seorang pekerja untuk bekerja biasanya merupakan hal yang rumit, karena motivasi ini melibatkan faktor-faktor individual dan faktor-faktor organisasional. Mangkunegara, (2017) menyatakan bahwa motivasi kerja dapat diukur melalui indikator sebagai berikut : 1) kerja keras, 2) orientasi masa depan, 3) tingkat cita-cita yang tinggi, 4) orientasi tugas/sasaran, 5) usaha untuk maju, 6) ketekunan, 7) rekan kerja, 8) pemanfaatan waktu.

\section{METODE PENELITIAN}

Jenis penelitian yang digunakan adalah penelitian survei. Pendekatan yang digunakan adalah deskripsi kuantitatif. Penelitian ini untuk melihat pengaruh pengawasan, budaya organisasi dan remunerasi terhadap motivasi kerja pegawai pada satuan kerja Biro Sumber Daya Manusia Polda Sumatera Utara. Populasi pada penelitian ini adalah seluruh pegawai yang bekerja pada satuan kerja Biro Sumber Daya Manusia Polda Sumatera Utara, yang berjumlah 86 orang. Adapun sebaran populasi penelitian ini tersebar berdasarkan bidang 
pekerjaan. Dalam penelitian ini seluruh populasi pegawai yang bekerja pada satuan kerja Biro Sumber Daya Manusia Polda Sumut sebanyak 86 pegawai dengan mengambil sebanyak 40 Pegawai Negeri Sipil sebagai sampel. Penelitian ini menggunakan Purposive Sampling / Judgement Sampling, dimana sampel dipilih dari suatu populasi berdasarkan pertimbangan ahli maupun pertimbangan ilmiah. Sebelum melakukan pengujian hipotesis dari penelitian ini, terlebih dahulu dilakukan pengujian asumsi klasik untuk memastikan bahwa alat uji regresi berganda dapat digunakan atau tidak dalam penelitian. Apabila uji asumsi klasik telah terpenuhi, maka alat uji statistik regreai linier berganda dapat pergunakan.

\section{HASIL DAN PEMBAHASAN}

\section{Uji Asumsi Klasik}

Sebelum melakukan pengujian hipotesis dari penelitian ini, terlebih dahulu dilakukan pengujian asumsi klasik untuk memastikan bahwa alat uji regresi berganda dapat digunakan atau tidak dalam penelitian. Apabila uji asumsi klasik telah terpenuhi, maka alat uji statistik regreai linier berganda dapat pergunakan.

Uji normalitas bertujuan untuk menguji apakah apakah dalam metode regresi, variabel terikat dan variabel bebas keduanya mempunyai distribusi normal atau tidak . Model regresi yang baik adalah data yang berdistribusi normal atau mendekati normal. Berikut adalah hasil pengujian normalitas dapat dilihat dari grafik probability plot:

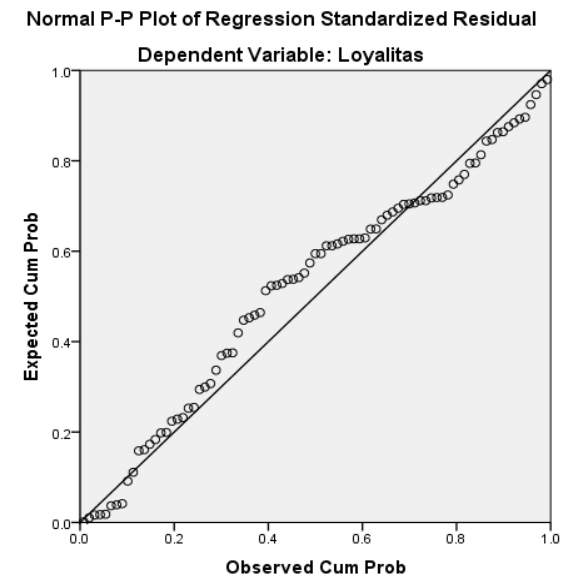

\section{Gambar 1. Hasil Pengujian Normalitas}

Pada gambar diatas diketahui hasil dari pengujian normalitas bahwa data menunjukkan penyebaran titik-titik data cenderung mendekati garis diagonal. Sehingga dapat disimpulkan bahwa data yang diolah merupakan data yang berdistribusi normal dan uji normalitas terpenuhi.

Multikolinieritas digunakan untuk menguji apakah pada model regresi ditemukan adanya korelasi yang kuat antar variabel independen. Cara yang digunakan untuk menilainya adalah dengan melihat nilai faktor inflasi varians (Variance Inflasi Factor/VIF), yang tidak melebihi 4 atau 5.

\section{Tabel 1. Hasil Pengujian Multikolinearitas} Coefficients $^{\mathrm{a}}$

\begin{tabular}{|c|c|c|c|}
\hline \multirow[t]{2}{*}{ Model } & & \multicolumn{2}{|c|}{ Collinearity Statistics } \\
\hline & & Tolerance & VIF \\
\hline \multirow{4}{*}{1} & (Constant) & & \\
\hline & Kepemimpinan & .245 & 3.088 \\
\hline & Kepuasan Kerja & .278 & 3.600 \\
\hline & Motivasi & 713 & 1.403 \\
\hline
\end{tabular}


Ketiga variabel independent yaitu $X_{1}, X_{2}$ dan $X_{3}$ memiliki nilai VIF dalam batas toleransi yang telah ditentukan yaitu 3,088, 3,600 dan 1,403 (tidak melebihi 4 atau 5) sehingga tidak terjadi multikolonieritas dalam variabel independen penelitian ini.

Pengujian ini memiliki tujuan untuk mengetahui apakah dalm model regresi terjadi ketidaksamaan varian dari residual suatu pengamatan ke pengamatan lainnya. Jika varian dari residual satu pengamatan ke pengamatan lain tetap, maka disebut homokedassitas dapat diketahui dengan melalui grafik scatterplot antar nilai prediksi varabel independen dengan nilai residualnya (Juliandi, Irfan, \& Manurung, 2015).

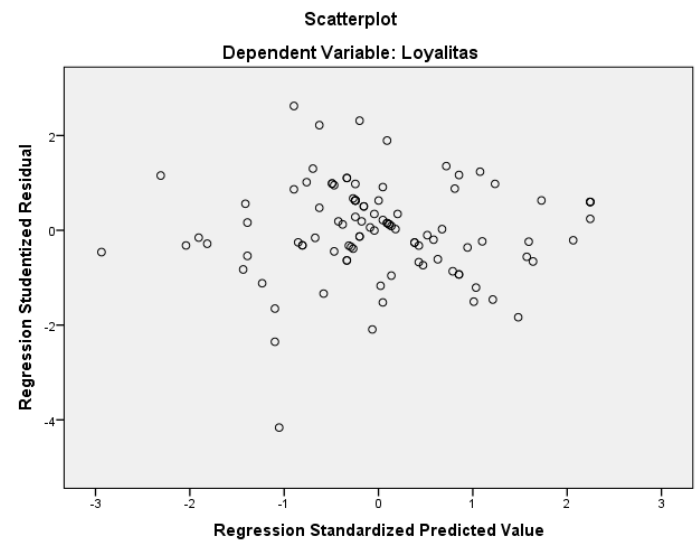

\section{Gambar 2. Hasil Pengujian Heteroskedasitas}

Dari gambar grafik scatterplot diatas dapat diketahui bahwa tidak terjadi heteroskedastisitas pada model regresi ini. Sebab tidak ada pola yang jelas serta titik-titik menyebar diatas dan dibawah angka 0 pada sumbu Y, maka kesimpulannya tidak terjadi heteroskedasitas.

\section{Pengujian Hipotesis}

\section{Uji t (Secara Parsial)}

Tujuan dari Uji $t$ adalah untuk melihat apakah ada hubungan yang signifikan atau tidak dalam hubungan antara variabel $\mathrm{X}_{1}, \mathrm{X}_{2}$ dan $\mathrm{X}_{3}$ terhadap $\mathrm{Y}$. data tersaji pada tabel di bawah ini, adapun $t$ tabel $=1,66$ (lihat tabel $t$ untuk $\mathrm{N}=85$ ).

Tabel 2. Uji t

\begin{tabular}{|c|c|c|c|c|c|c|}
\hline \multicolumn{7}{|c|}{ Coefficients $^{\mathrm{a}}$} \\
\hline \multirow{2}{*}{\multicolumn{2}{|c|}{ Model }} & \multicolumn{2}{|c|}{$\begin{array}{l}\text { Unstandardized } \\
\text { Coefficients }\end{array}$} & \multirow{2}{*}{$\begin{array}{c}\text { Standardized } \\
\text { Coefficients } \\
\text { Beta }\end{array}$} & \multirow[t]{2}{*}{$\mathrm{t}$} & \multirow[t]{2}{*}{ Sig. } \\
\hline & & B & Std. Error & & & \\
\hline \multirow{4}{*}{1} & (Constant) & -.946 & 2.463 & & -.384 & .702 \\
\hline & Kepemimpinan & .275 & .063 & .502 & 4.372 & .000 \\
\hline & Kepuasan Kerja & .124 & .146 & .092 & .854 & .396 \\
\hline & Motivasi & .395 & .067 & .395 & 5.867 & .000 \\
\hline
\end{tabular}

\section{Pengaruh Kepemimpinan terhadap Loyalitas}

Hasil pengujian diperoleh nilai $t$ untuk variabel Kepemimpinan menunjukkan nilai $t_{\text {hitung }}$ $=4,372>\mathrm{t}_{\text {tabel }}=1,66$ dengan nilai signifikansi sebesar $=0,000<0.05$ dengan demikian berarti Kepemimpinan memiliki pengaruh yang signifikan terhadap Loyalitas.

\section{Pengaruh Kepuasan Kerja terhadap Loyalitas}

Hasil pengujian diperoleh nilai t untuk variabel Kepuasan Kerja menunjukkan nilai t $=0,854<\mathrm{t}$ tabel $=1,66$ dengan nilai signifikansi sebesar $=0,396>0,05$ yang berarti 
menunujukkan bahwa Kepuasan Kerja tidak memiliki pengaruh yang signifikan terhadap Loyalitas.

\section{Pengaruh Motivasi terhadap Loyalitas}

Hasil pengujian diperoleh nilai $\mathrm{t}$ untuk variabel Motivasi menunjukkan nilai $\mathrm{t}=5,867>$ $\mathrm{t}$ tabel $=1,66$ dengan nilai signifikansi sebesar $=0,000<0,05$ yang berarti menunujukkan bahwa Motivasi memiliki pengaruh yang signifikan terhadap Loyalitas .

\section{Uji F (Secara Simultan)}

Hasil perhitungan Uji F disajikan pada tabel di bawah ini :

\begin{tabular}{llrrrrr}
\multicolumn{7}{c}{ Tabel 3. Uji F } \\
\hline \multicolumn{7}{c}{ ANOVA $^{\mathbf{a}}$} \\
\hline Model & & Sum of Squares & df & Mean Square & F & \multicolumn{1}{c}{ Sig. } \\
\hline \multirow{3}{*}{1} & Regression & 487.352 & 3 & 162.451 & 76.299 & $.000^{\text {b }}$ \\
\cline { 2 - 8 } & Residual & 172.459 & 81 & 2.129 & & \\
\cline { 2 - 8 } & Total & 659.812 & 84 & & & \\
\hline
\end{tabular}

a. Dependent Variable: Loyalitas

b. Predictors: (Constant), Motivasi, Kepuasan Kerja, Kepemimpinan

Dari hasil pengolahan data di atas terlihat bahwa nilai $\mathrm{F}_{\text {hitung }}=76,299>$ dari $\mathrm{F}_{\text {tabel }}=2,70$ (lihat tabel $\mathrm{F}$ untuk $\mathrm{N}=85$ ) dengan nilai probabilitas yakni sig adalah sebesar 0,000<0,05. Artinya Kepemimpinan, Kepuasan kerja dan Motivasi secara bersama-sama berpengaruh signifikan terhadap Loyalitas , maka keputusannya Hipotesis diterima.

\section{Koefisien Determinasi $\left(\mathbf{R}^{2}\right)$}

Koefisien determinasi ini digunakan untuk mengetahui seberapa besar pengaruh variabel-variabel bebas memiliki pengaruh terhadap variabel terikatnya. Nilai koefisien determinasi ditentukan dengan nilai $R$ square.

Tabel 4. Koefisien Determinasi Model Summary ${ }^{b}$

\begin{tabular}{|c|c|c|c|c|c|c|c|}
\hline \multirow[t]{2}{*}{ Model } & \multirow[t]{2}{*}{$\mathrm{R}$} & \multirow[t]{2}{*}{ R Square } & \multirow{2}{*}{$\begin{array}{c}\text { Adjusted R } \\
\text { Square }\end{array}$} & \multirow{2}{*}{$\begin{array}{l}\text { Std. Error of the } \\
\text { Estimate }\end{array}$} & \multicolumn{3}{|c|}{ Change Statistics } \\
\hline & & & & & $\begin{array}{l}\text { R Square } \\
\text { Change }\end{array}$ & $\begin{array}{c}\mathrm{F} \\
\text { Change }\end{array}$ & df1 \\
\hline 1 & $.859^{\mathrm{a}}$ & .739 & .729 & 1.45915 & .739 & 76.299 & \\
\hline
\end{tabular}

Dari hasil pengolahan data di atas terlihat bahwa nilai koefisien korelasi (R Square) sebesar 0,739, hal ini berarti Kepemimpinan, Kepuasan kerja dan Motivasi secara bersama-sama berpengaruh sebesar 73,9\% sedangkan sisanya 26,1,1\% Loyalitas dipengaruhi oleh variabel lain yang tidak ada dalam penelitian ini seperti kompensasi, beban kerja, stress kerja, lingkungan kerja dan sebagainya.

\section{PEMBAHASAN}

\section{Pengaruh Kepemimpinan Terhadap Loyalitas Karyawan}

Kepemimpinan merupakan salah satu faktor yang menentukan kelangsungan hidup suatu perusahaan. Kedudukan pemimpin dalam perusahaan mempunyai peran penting terhadap keberhasilan atau kegagalan dalam mencapai sasaran yang telah ditentukan perusahaan. Perlu disadari bahwa pemimpin perusahaan bertanggung jawab terhadap masalah sumber daya manusia yang ada dengan memperhatikan segi peningkatan kualitas tenaga kerja serta semangat kerja yang tinggi untuk mencapai loyalitas karyawan yang tinggi. Apabila seorang pemimpin mampu meningkatkan semangat dan kegairahan kerja karyawan, maka diharapkan loyalitas karyawan akan meningkat. Sebaliknya, apabila seorang pemimpin tidak mampu meningkatkan semangat dan kegairahan kerja karyawan, maka loyalitas karyawan akan 
menurun, tingkat absensi akan meningkat, tingkat kedisiplinan akan menurun, dan adanya hal-hal yang dapat merugikan perusahaan.

Hasil penelitian ini menunjukkan bahwa kepemimpinan berpengaruh terhadap loyalitas, hal ini berarti keputusan-keputusan yang diambil pimpinan, support yang diberikan pimpinan kepada karyawan, komunikasi yang baik dari pimpinan dan sikap pemimpin yang baik dapat mempengaruhi loyalitas karyawan untuk bekerja dengan baik. Pemimpin yang mampu memberikan kenyamanan bagi karyawannya kan memberikan dampak positif bagi karyawan untuk bersikap loyal terhadap perusahaan.

Pada PT Perkebnunan Nusantara IV (Persero) para karyawan menilai suasana kepemimpinan yang terjadi telah berjalan dengan baik dan memberikan kenyamanan bagi karyawan dalam bekerja, karyawan merasa lebih semangat dan lebih percaya diri dalam mengerjakan tugas-tugas yang ditetapkan. Sehingga dengan kondisi tersebut meningkatkan loyalitas karyawannya. Hasil penelitian ini mendukung penelitian sebelumnya yang dilakukan oleh (Kitriawaty, Setiawati, \& Sumantri, 2017); (Wulandari \& Utami, 2018) dan (Carolina \& Halim, 2017) yang menunjukkan bahwa kepemimpinan berpengaruh signifikan terhadap loyalitas.

\section{Pengaruh Kepuasan Kerja Terhadap Loyalitas Karyawan}

Kepuasan kerja adalah sikap positif atau negatif seorang karyawan terhadap pekerjaannya. Kepuasan kerja merupakan hasil interaksi karyawan dengan lingkungan/tempat kerjanya, sehingga tingkat kepuasan kerja seseorang berbeda-beda. Kepuasan kerja diharapkan mengarah pada pencapaian loyalitas kerja yang tinggi. Salah satu pandangan loyalitas karyawan menyatakan bahwa loyalitas kerja akan tercipta apabila karyawan merasa tercukupi dalam memenuhi kebutuhan hidup dari pekerjaannya, sehingga mereka betah bekerja dalam suatu perusahaan. Hasil penelitian ini menunjukkan bahwa kepuasan kerja tidak berpengaruh terhadap loyalitas. Dengan demikian dapat dianalisis bahwa faktor karyawan dan faktor pekerjaan yang menjadi indikator kepuasan karyawan tidak memberikan pengaruh terhadap loyalitas karyawan, karyawan menganggap kepuasan kerja mereka tidak ditentukan oleh karyawan-karyawan lain dan juga tidak ditentukan oleh jenis pekerjaan yang diberikan oleh perusahaan. Pada PT Perkebunan Nusantara IV (Persero) karyawan dapat tetap bekerja dengan baik dan tetap merasa puas tanpa didasari oleh rekan kerja dan juga jenis pekerjaannya, para karyawan sudah terbiasa bekerja dengan rekan kerja dan jenis pekerjaan yang diberikan oleh perusahaan sehingga bukan factor tersebut yang memberikan kepuasan bagi karyawan.

Hasil penelitian ini tidak mendukung penelitian sebelumnya yang dilakukan oleh hasil penelitian yang dilakukan (Wibowo \& Sutanto, 2013); (Basalamah, 2012) dan (Wulandari \& Utami, 2018) yang menunjukkan bahwa kepuasan kerja memiliki pengaruh positif dan signifikan terhadap loyalitas karyawan.

\section{Pengaruh Motivasi Terhadap Loyalitas Karyawan}

Salah satu faktor penting yang mempengaruhi loyalitas kerja karyawan adalah motivasi. Motivasi kerja adalah sesuatu yang dapat menimbulkan semangat dan dorongan untuk bekerja. Motivasi dapat bersumber dari internal maupun eksternal. Teori motivasi dapat digolongkan menjadi dua yaitu teori kepuasan atau content theory dan process theory. Motivasi eksternal dapat bersumber dari organisasi, sehingga menjadi tugas manager untuk menciptakan lingkungan kerja yang dapat menimbulkan adanya suatu motivasi. Loyaltias kerja dipengaruhi oleh motivasi, oleh sebab itu individu yang memiliki motivasi tinggi cenderung lebih loyal daripada individu yang memiliki motivasi yang rendah. Dalam era globalisasi yang penuh dengan persaingan yang ketat, setiap organisasi sebaiknya memperbaiki dan meningkatkan 
loyaltias kerjanya. Dengan loyalitas kerja yang tinggi diharapkan daya saing organisasi menjadi lebih baik dan keuntungan juga meningkat. Hasil penelitian ini menunjukkan bahwa motivasi berpengaruh terhadap loyalitas, hal ini berarti keinginan untuk hidup bahagia, keinginan dapat memiliki sesuatu, keinginan mendapatkan penghargaan, kondisi lingkungan kerja dan supervise yang baik akan memberikan semangat bekerja yang mempengaruhi tingkat loyalitas karyawan kepada perusahaan. Pada PT Perkebunan Nusantara IV (Persero) motivasi-motivasi yang diberikan perusahaan telah mampu meningkatkan loyalitas karyawan, baik dari segi kompensasi, jaminan pekerjaan dan peraturan yang fleksibel. Motivasi dalam diri karyawan juga menunjukkan hal positif dilihat dari semangat bekerja yang ditunjukkan oleh para karyawannya. Hasil penelitian ini mendukung penelitian sebelumnya yang dilakukan oleh (Kitriawaty et al., 2017) dan (Maharani, 2018) yang menunjukkan bahwa motivasi berpengaruh signifikan terhadap loyalitas.

\section{Pengaruh Kepemimpinan, Kepuasan Kerja dan Motivasi terhadap Loyalitas Karyawan}

Loyalitas karyawan merupakan faktor terpenting untuk mencapai suatu tujuan perusahaan. Loyalitas karyawan dapat tercipta dengan adanya gaya kepemimpinan, kepuasan kerja serta motivasi kerja karyawan yang tercipta dengan baik di dalam perusahaan. Oleh karena itu, perusahaan perlu menerapkan gaya kepemimpinan yang baik sesuai dengan para anggota perusahaan, serta perusahaan harus mampu memberikan kepuasan kerja dan motivasi kerja yang baik juga kepada karyawannya. Hasil penelitian (Chandra, 2015) menunjukkan adanya pengaruh yang signifikan antara kepemimpinan terhadap loyalitas pegawai, budaya organisasi terhadap loyalitas pegawai, motivasi terhadap loyalitas pegawai dan kompetensi terhadap loyalitas pegawai. Terdapat pengaruh secara simultan antara kepemimpinan, budaya organisasi, motivasi dan kompetensi terhadap loyalitas pegawai. Terdapat pengaruh antara loyalitaspegawai terhadap kinerja pegawai.

\section{KESIMPULAN}

Berdasarkan pada hasil analisis regresi linier berganda yang telah dilakukan pada penelitian ini, didapat kesimpulan sebagai berikut Kepemimpinan memiliki pengaruh terhadap loyalitas karyawan PT Perkebunan Nusantara (Persero) IV, hal ini berarti semakin baik kepemimpinan akan meningkatkan loyalitas karyawan. Kepuasan Kerja tidak memiliki pengaruh terhadap loyalitas karyawan PT Perkebunan Nusantara (Persero) IV hal ini berarti baik atau tidaknya kepuasan kerja tidak berbanding lurus dengan loyalitas karyawan. Motivasi memiliki pengaruh terhadap loyalitas karyawan PT Perkebunan Nusantara (Persero) IV, hal ini berarti semakin baik motivasi yang diberikan akan meningkatkan loyalitas karyawan. Kepemimpinan, Kepuasan Kerja dan Motivasi secara bersama-sama memiliki pengaruh terhadap loyalitas karyawan PT Perkebunan Nusantara (Persero) IV.

Adapun saran-saran yang dapat direkomendasikan adalah sebagai berikut Dalam kaitannya dengan Kepemimpinan, kepemimpinan yang telah dimiliki oleh atasan dianggap masih harus ditingkatkan, karyawan menginginkan atasan mampu memotivasi dan meningkatkan kedisiplinan dan kerjasama antar karyawan. Dalam kaitannya dengan Kepuasan Kerja , Kepuasan kerja yang dimiliki oleh karyawan sudah cukup baik, hanya beberapa orang saja yang masih menyatakan belum puas bekerja di perusahaan, apalagi terkait dengan aturan kerja yang ditetapkan perusahaan dalam hal waktu bekerja. Dalam kaitannya dengan motivasi, motivasi yang diberikan perusahaan telah mampu meningkatkan loyalitas karyawan sehingga diharapkan perusahaan dapat mempertahankan dan meningkatkan pemberian motivasi apalagi terkait dengan kompensasi atau bonus yang diberikan. Untuk penelitian yang akan datang disarankan untuk menambah variabel independen lainnya selain kepemimpinan, kepusan kerja 
dan motivasi yang tentunya dapat mempengaruhi variabel dependen Kinerja Karyawan . Juga menambahkan jumlah sampel dan kriteria sampel, sehingga target penelitian dapat tercapai dengan baik.

\section{DAFTAR PUSTAKA}

Almasdi, J. S. (2012). Aspek Sikap Mental Dalam MSDM. Jakarta: Syiar Media.

Arianty, N., Bahagia, R., Lubis, A. A., \& Siswadi, Y. (2016). Manajemen Sumber Daya Manusia. Medan: Perdana Publishing.

Basalamah, A. (2012). Pengaruh Kepuasan Kerja Terhadap Loyalitas Staf Reception pada Hotel X di Madiun. Binus Business Review, 3(1), 493-501.

Carolina, S., \& Halim, G. A. (2017). Analisis Pengaruh Gaya Kepemimpinan terhadap Loyalitas Karyawan Hotel X Bali. Jurnal Hospitality Dan Manajemen Jasa, 5(2), 328341.

Chandra, B. T. (2015). Pengaruh kepemimpinan, motivasi, budaya organisasi dan kompetensi pegawai terhadap loyalitas serta implikasinya pada kinerja pegawai Perkebunan Teh PTPN VIII Jawa Barat. Universitas Pasundan.

Colquitt, J., LePine, J., \& Wesson, M. (2012). Organizational Behavior: Improving Performance and Commitment in the Workplace (3rd ed.). New York: McGraw-Hill Education.

Gomes, F. C. (2009). Manajemen Sumber Daya Manusia. Yogyakarta: Andi Offset.

Hasibuan, M. S. . (2014). Manajemen Sumber Daya Manusia. Jakarta: Bumi Aksara.

Jufrizen, J. (2016). Efek Mediasi Kepuasan Kerja Pada Pengaruh Kompensasi Terhadap Kinerja Karyawan. Jurnal Ilmiah Manajemen Dan Bisnis, 17(1).

Jufrizen, J. (2017). Pengaruh kemampuan dan motivasi terhadap kinerja perawat Studi pada Rumah Sakit Umum Madani Medan. Jurnal Riset Sains Manajemen, 1(1), 27-34. https://doi.org/10.5281/zenodo.1036809

Jufrizen, J. (2017). Efek Moderasi Etika Kerja Pada Pengaruh Kepemimpinan Transformasional dan Budaya Organisasi Terhadap Kinerja Karyawan. E-Mabis : Jurnal Ekonomi Manajemen Dan Bisnis, 18(2), 145-158.

Jufrizen, J., \& Pulungan, D. R. (2017). Implementation of Incentive and Career Development of Performance with Motivation as an Intervening Variable. In Proceedings of AICS-Social Sciences (pp. 441-446).

Juliandi, A., Irfan, \& Manurung, S. (2015). Metodologi Penelitian Bisnis. Medan: UMSU Press.

Kartono, K. (2014). Pemimpin dan Kepemimpinan. Jakarta: PT Raja Grafindo Persada.

Kitriawaty, D., Setiawati, E. P., \& Sumantri, S. (2017). Pengaruh Kepemimpinan Dan Motivasi Terhadap Loyalitas Perawat Rumah Sakit Swasta Tipe B Di Kota Bandung. Jurnal Sistem Kesehatan, 3(1), 1-7. https://doi.org/10.24198/jsk.v3i1.13964

Luthans, F. (2010). Organizational behavior: An Evidence-Based Approach (12th ed.). New York: McGraw-Hill/Irwin.

Maharani, L. P. (2018). Pengaruh kompensasi, motivasi, dan lingkungan kerja terhadap loyalitas guru Genius di Yatim Mandiri Surabaya. Undergraduate thesis, UIN Sunan Ampel Surabaya.

Mangkunegara, A. A. P. (2017). Manajemen Sumber Daya Manusia (Bandung). Remaja Rosdakarya.

Mujiatun, S., Jufrizen, J., \& Ritonga, P. (2019). Model Kelelahan Emosional: Antaseden Dan Dampaknya Terhadap Kepuasan Kerja Dan Komitmen Organisasi Dosen. MIX: Jurnal Ilmiah Manajemen, 9(3), 447-465. 
Nitisemito, A. S. (2011). Manajemen Personalia (Manajemen Sumber. Daya Manusia) (14th ed.). Jakarta: Ghalia Indonesia.

Putri, S. I. (2014). Pengaruh Gaya Kepemimpinan dan Loyalitas Karyawan Terhadap Kinerja Karyawan pada PT. Kurnia Alam Perista Kudus. akultas Ekonomika dan Bisnis Universitas Diponegoro Semarang.

Robbins, S. P., \& Judge, T. A. (2011). Organizational Behavior (14th ed.). New Jersey: Prentice Hall.

Setiawan, B. A., \& Muhith, A. (2013). Transformasional Leadership: Ilustrasi di Bidang Organisasi Pendidikan. Jakarta: Rajawali Pers.

Siagian, S. P. (2014). Manajemen Sumber Daya Manusia. Jakarta: Bumi Aksara.

Soeroso, S. (2004). Manajemen Sumber Daya Manusiadi Rumah Sakit; Suatu Pendekatan Sistem. Jakarta: Penerbit Buku Kedokteran EGC.

Sutikno, S. (2014). Pemimpin dan Kepemimpinan. Lombok: PT. Holistica.

Wibowo. (2006). Manajemen Perubahan. Jakarta: Raja Gradindo Persada.

Wibowo. (2013). Manajemen Kinerja. Jakarta: Rajawali Pers.

Wibowo, J., \& Sutanto, E. M. (2013). Pengaruh Leader Member Exchange (LMX), Motivasi Kerja dan Kepuasan Kerja terhadap Loyalitas Karyawan Departemen Penjualan CV. Pratama Jaya di Madiun. AGORA, l(3).

Wulandari, P., \& Utami, H. N. (2018). Hubungan Kepemimpinan dan Kepuasan Kerja terhadap Loyalitas Pegawai PT Pembangkitan Jawa Bali. Jurnal Administrasi Bisnis (JAB), 65(1), $19-26$.

Yukl, G. (2010). Leadership in Organization (7th ed.). New Jersey: Pearson Education. 